\title{
Transnational Science Cooperation for Sustainable Development
}

\author{
Anna Schwachula
}

\subsection{INTRODUCTION}

Transnational research cooperation between partners in the Global South and the Global North is an under-researched but relevant topic, often overlooked in the context of development cooperation and development research. In this contribution, I argue that changing ideas about development also require changes in the mode of inter- and transnational cooperation. With a shift towards "global development", the previous emphasis on necessary change in "developing countries" moved towards an emphasis on the need for transformation in all countries (Horner and Hulme 2017; Hulme 2016). If all nations are perceived as "developing countries" in certain aspects of social, economic, or ecological sustainable development, previous cooperation patterns, which often imply North-South knowledge hierarchies, have to be reassessed, and additional types of cooperation for global sustainable development should be examined.

Cooperation in research, or more generally in science, ${ }^{1}$ between researchers in the Global North and South ${ }^{2}$ can be considered, as such an additional type of transnational cooperation, beyond established approaches of technical development cooperation. Transnational research cooperation, as well as the policies that frame it nationally and globally, thus fall into the context of

\footnotetext{
A. Schwachula $(\bowtie)$

German Development Institute / Deutsches Institut für Entwicklungspolitik (DIE), Bonn, Germany

e-mail: anna.schwachula@die-gdi.de

(C) The Author(s) 2021 
the discussions around the future of development cooperation "beyond aid" (Horner and Hulme 2017; Janus et al. 2015).

However, so far, the potential of transnational research cooperation is little acknowledged, both within the community of development research and in global debates and governance mechanisms for sustainable development, such as the 2030 Agenda for Sustainable Development or the Global Partnership for Effective Development Co-operation (GPEDC). The role of science cooperation for sustainable development is much less recognised in development practice, policy, and research than the role of other types of knowledge cooperation, such as capacity development or knowledge transfer (see Sect. 4.2). I put forward, however, that transnational research cooperation for sustainable development should be endorsed by global agreements and national policies.

Transnational research cooperation can contribute to identifying and establishing potential pathways towards equitable sustainable development. In the ideal case, cooperative transnational and transdisciplinary research comes up with solutions that are relevant to stakeholders and can be implemented in and adapted to local contexts (Hirsch Hadorn et al. 2006; Lang et al. 2012). ${ }^{3}$ Furthermore, jointly producing new knowledge as well as exchanging knowledge on equal terms should be emphasised as suitable modes of cooperation. Modes of equitable cooperation correspond more smoothly with the new paradigm of global sustainable development than traditional North-South knowledge transfer or capacity development.

Lastly, I argue that stronger global agreements might also contribute to better policy coherence for development at the national level, where transnational research cooperation may be part of science policy-as in the German case-which may have objectives that diverge from development policy. Put differently, in view of sustainability-oriented transnational research cooperation, the current gaps in global governance may aggravate policy incoherence on the national level, with potentially detrimental effects on sustainable development. Hence, this chapter also provides an illustration of the concepts of the challenge of coordinating policy-making on the national and global levels and of the contested objectives and responsibilities of different policy fields, which are introduced in the introduction to this handbook.

In this contribution, I elaborate on the role of knowledge (Sect. 4.2), science as a specific type of knowledge, and the role of research cooperation for sustainable development (Sect. 4.3) before I examine the role of national policies - along the example of German science and development policy-and global norms for transnational research cooperation between partners from the Global North and the Global South (Sect. 4.4). In Sect. 4.5, I draw some conclusions in view of the existing gaps in the framework of global governance for transnational research cooperation for sustainable development.

This contribution is based on empirical qualitative research on German science policy for cooperation between Germany and the Global South in sustainability research, carried out in the framework of my Ph.D. (Schwachula 2019). 


\subsection{Knowledge and Development}

Without explicitly referring to knowledge as a driver of development or making its role explicit, development practice and development policy have been closely interlinked with knowledge since colonial times (Hornidge 2014a). This is a relevant fact, as I propose here to define science as a specific type of knowledge, distinguished from other types only through its specific rules of production (Knorr-Cetina 1999; Sismondo 2008). This perspective on knowledge and science as socially shared definitions of phenomena is grounded in a constructivist approach, more specifically in the Sociology of Knowledge Approach to Discourse (Keller 2005, 2013).

With science being perceived as a type of knowledge, it is therefore necessary to contemplate the role of knowledge in development in general, before scrutinising in depth the role of science cooperation between partners in the Global North and the Global South. Putting science into context seems particularly relevant, as the role of knowledge, and more so science, has been discussed controversially in view of development.

In an everyday understanding, knowledge is defined as internalised information and as an "understanding of or information about a subject that you get by experience or study, either known by one person or by people generally" ("Knowledge" 2018). In a more encompassing understanding, constructivist scholars propose to define knowledge as a socially shared and accepted perception of phenomena that is considered to be objective and valid, and therefore perceived as legitimate (Keller 2013). In pointing at the socially constructed nature of knowledge, the constructivist perspective substantially diverges from a positivist perception of objective reality.

In view of knowledge in the development context, the constructivist approach is helpful, as it emphasises the interconnections between knowledge and power, which are inherent in any context of cooperation between different partners in the Global North and South. "Knowledge" then "refers to everything which is supposed to 'exist' (including ideas, theories, everyday assumptions, language, incorporated routines and practices)" (Keller 2005, p. 6). Knowledge and power are connected through the embeddedness of knowledge in discourses and corresponding "dispositifs", that is, discourse-related institutions and structures (Foucault 1980; Keller 2013).

Among other effects, discursive power becomes evident in the validity, objectivity, truth, or value attributed to specific types of knowledge and the social groups creating this knowledge, while other types of knowledge are discredited. Institutionalised power and resources, such as financial, cultural, or social capital, influence whose knowledge is counted as legitimate and spread (Keller 2003, 2013). In view of the role of knowledge for development, this is essential, as the next section shows.

Next to knowledge that is counted in social terms as being essential, and therefore transmitted in formal education systems, different types of knowledge with different social attributions of credibility coexist. Knowledge spans 
from everyday, tacit lay knowledge to explicit, highly specialised forms of knowledge, such as scientific knowledge or traditional, local knowledge on specific aspects of our life world. The importance of these different knowledge types for development is increasingly being recognised (Arocena and Sutz 2012; Leach et al. 2012; Smith et al. 2014). Compared to other types of knowledge, scientific knowledge is often counted as the most neutral, objective, and therefore legitimate-even if, from a constructivist perspective, scientific knowledge is considered to be only one type of knowledge among others, differentiating itself only through its specific rules of production (Knorr-Cetina 1999; Sismondo 2008). ${ }^{4}$

\subsubsection{Knowledge for Development: A Tense Relation}

Since colonial times, the definition of development has been predominantly shaped in the Global North, at the expense of Southern perspectives. In consequence, the uneven distribution of power and accepted knowledge has also shaped development cooperation in practice (della Faille 2011; Escobar 1992; Esteva 2010; Gardner and Lewis 2000; Gore 2000; Nederveen Pieterse 2011; Ziai 2010, 2015). Development thinking was firmly based on the belief of the superiority of Western knowledge and the model of Western/Northern modernity, to be followed as a pathway to development, which was understood to be the modernisation of traditional societies. Modernity and development meant triggering economic growth and introducing modern institutions, values, and norms. In this development paradigm, non-Western knowledge was neglected and devaluated (Cowen and Shenton 2003; Crewe and Harrison 1998). Modernisation theory and its assumptions of knowledge for development have been criticised for many years, among other reasons for being too simplistic (Chataway et al. 2006), too linear (Evers 2000), for implying an expert lay hierarchy (Illi 2001; Sillitoe 2000), or for maintaining North-South hierarchies and technological dependence (Shamsavari 2007).

In the Global South, some countries, such as Brazil, China, India, and Mexico, among others, have developed strong science systems-backed by public and private investments in research-and turned into global players in science production (UN Educational, Scientific and Cultural Organization 2015). At the same time, development policy and practice are opening up to different conceptualisations, including Southern knowledge and perspectives. For example, the concept of "Buen Vivir" as a Southern vision of development is widely known in the development community (Acosta Espinosa 2008). Moreover, the development paradigm, as such, is shifting towards more equitable knowledge/power relations, as evident in the increased focus on ownership, partnership, and the local suitability of interventions in NorthSouth cooperation, a shift towards a global perspective on development, and the rise of South-South cooperation as an additional type of development cooperation (Janus et al. 2015). 
While knowledge, power, and development are closely interrelated in determining the very idea of the latter, knowledge has also turned into a subject of development policy and practice. Institutions such as the World Bank (1999) firmly introduced "knowledge for development" on the agenda of development policy and practice (Evers et al. 2006), uncritically picturing knowledge as a panacea for development-that is, knowledge produced elsewhere to be used in the context of the Global South. Knowledge is viewed as a precondition and driver of (sustainable) development. Making knowledge useable for development consequently has turned into a normative goal pursued by many governments and institutions, often in view of the economic usability of knowledge (Hornidge 2012, 2014a).

Different scholars have contested the simplistic idea that knowledge is a silver bullet for development and have painted a more differentiated picture instead. While generally affirming the important role of knowledge in sustainable development, the scientific community acknowledges that, next to the inherent relation between knowledge and power, knowledge is surrounded by different types of social, legal, political, and technical boundaries (see among others, Evers 2000; Evers et al. 2006; Hornidge 2013). In addition, certain aspects of the concept of "knowledge for development" are debated-such as its best use (Narayanaswamy 2013); the role of local or indigenous knowledge; and the problems of conceptualising it as the opposite of scientific or expert knowledge (Agrawal 1995; Mosse 2001; Sillitoe 2000).

Even in a contested area such as knowledge and (or for) development, some things are not disputed, however. This includes the importance of primary and secondary education and the knowledge transmitted by it, including basic factual and practical types of knowledge as well as knowledge-related skills, such as literacy (Klochikhin 2012). The value attributed to basic education and knowledge is reflected in national development policies as well as their international framing: Transmitting knowledge through education was one of the Millennium Development Goals and included in the Sustainable Development Goals (SDGs) as well (United Nations [UN] 2015; UN Development Programme [UNDP] 2013).

Basic education is even used as an indicator for development: Both the Human Development Index as well as the Multidimensional Poverty Index include knowledge-measured through average and expected years of schooling - as indicators (UNDP 2018). Primary, secondary, and tertiary education as well as capacity development continue to be a focus of development policies worldwide. In Germany, for example, basic education is well-established as a subfield of national education policy as well as international development policy (German Federal Ministry of Education and Research [BMBF] 2016; German Federal Ministry for Economic Cooperation and Development [BMZ] 2015).

Next to the formal education system, knowledge cooperation may also take place in the form of capacity development or knowledge transfer in different sectors, for example, through vocational training in specific fields of expertise. 
While the role of education and capacity development is mainly to transmit knowledge from one individual or institutional actor-often from a donor country-to another, more recently emphasis has also been put on knowledge exchange, with knowledge being shared among partners in both directions. Here, the focus ideally is on mutual learning (Arocena and Sutz 2010; Bradley 2007; Upreti 2011). The 2030 Agenda puts knowledge sharing at the heart of SDG 17. Online platforms such as the United Nation's (UN) SDG Knowledge Platform (UN Department of Economic and Social Affairs 2019) and the GPEDC Knowledge Platform (Global Partnership for Effective Development Co-operation [GPEDC] 2019) similarly target virtual knowledge sharing for sustainable development. According to Janus et al. (2015), next to perceiving development as a global phenomenon, it is a further feature of "beyond aid" to emphasise the role of knowledge exchange among partners from different societal sectors and different world regions. However, knowledge sharing is still to be differentiated from the joint production of new knowledge on specific phenomena, as enabled in research cooperation.

\subsection{Transnational ResEarch Cooperation for Sustainable Development}

A further type of knowledge cooperation is the production of new scientific insights in research cooperation. Indeed, the idea of turning science into a lever of a development process can be traced back to colonial times (Smith 2009). In general, however, "science for development" meant that scientific knowledge produced in the Global North was to be used in development contexts of the Global South-the idea of science for development was thus coupled to the modernist ideas of knowledge and technology transfer from North to South (Hornidge 2014b). Until today, Southern scientific knowledge is not well represented in influential scientific journals, and Southern scientists are not sufficiently integrated in institutions supporting the scientific knowledge system, such as editorial boards (Cummings and Hoebink 2017). In consequence, Southern scientific perspectives are globally less visible. This exclusion from institutions of global science production and representation also entails that the research agendas on topics concerning the Global South are set in the Global North (Landau 2012).

Taking the interlinkages between knowledge production and power into consideration helps to explain why these skews in global knowledge production continue to exist. In a vicious circle, the science system favours Northern "experts" and scientific knowledge while excluding Southern knowledge, in consequence reinforcing dependencies and inequalities. However, countries of the Global South are increasingly interested in establishing their own science systems in the expectation of gaining the potential benefits of science on economic, social, and environmental development (Conway et al. 2010). ${ }^{5}$ 
At the same time, research cooperation among Southern and Northern partners on equal terms becomes more important. It is portrayed as a means of linking up to international state-of-the-art research, of accessing different bodies of knowledge, and of connecting with global scientific networks (Commission for Research Partnerships with Developing Countries [KFPE] 2010; Conway et al. 2010; The Royal Society 2011). Strong cooperation patterns have traditionally been in place among researchers in Northern countries. Cooperation between the Global North and the emerging powers of the Global South has become stronger in the last decades as well, with transnational cooperation framed through bilateral science agreements on the national level. To a lesser extent, research cooperation takes place between partners of the Global North and Southern countries classified as lowermiddle-income or least-developed countries, within patterns of South-South research cooperation, or as trilateral cooperation (BMBF 2014a, 2016).

Cooperation in research can assume different shapes, ranging from short- or long-term staff exchanges and individual scholarships for international mobility to cooperation in joint international projects and institutional twinning or creating joint research institutions. Research cooperation, as such, differs from development cooperation in not having a predefined normative objective. It may cover all areas of science and research-from basic, disciplinary research to inter- and transdisciplinary cooperation in applied sciences. Research cooperation can be aimed at pure knowledge creation without any further objectives of knowledge application, but it might also target objectives beyond science, then being defined as applied research. Next to economic usability-often the primal aim of applied science and science policy - research may pursue other targets, such as ecological sustainability (Jahn 2013; Smith et al. 2010; Ziegler 1998), or social aspects of "development", such as contributing to social equity or making better political decisions (Ely et al. 2010; Gibbons et al. 1994; Jasanoff 2003; Nowotny et al. 2001; Sarewitz et al. 2004; Sismondo 2008).

\subsubsection{Science and Sustainable Development}

In most societies, "autonomous" and curiosity-driven types of science coexist with "relevant" and problem-focussed types of science (Kaldewey 2013). At the same time, the role of science in and for society in general-or sustainable development in particular-is being debated (Glerup and Horst 2014; also see Stock and Schneidewind 2014).

I would like to propose two potentially conducive relations between science and sustainable development: Science on sustainable development and science for sustainable development. These are closely related to the concepts of transformation science and transformative science (German Advisory Council on Global Change [WBGU] 2011, 2016), while extending their scope. Science on sustainable development encompasses all types of research in the field that create new insights on sustainable development. It fills knowledge gaps and 
scientifically analyses problems in all areas of sustainable development, such as the effects of climate change, natural resource depletion, social inequalities, interdependencies between dimensions of sustainable development, etc. Given the complexity of sustainable development, as such, many fields of basic and applied research potentially produce relevant knowledge on sustainable development. In addition, research on sustainable development also deals with potential social and technological transformation processes, examines path dependencies and barriers preventing transformations, builds scenarios for different pathways towards sustainability, etc. Progress monitoring and measuring or indicator development for sustainability-related global agreements, such as the Paris Climate Agreement and the 2030 Agenda, are further fields of research on sustainable development.

In contrast, science for sustainable development is solutions-oriented research that is potentially aimed at transformative change. Researchers engaged in this type of applied research develop different types of solutions or innovations on different scales to target different dimensions of sustainable development. While technical innovations are often prominent, solutions could equally address social practices or governance, including science-based policy advice for sustainable development. If science is viewed in terms of its relevance and applicability for sustainable development, a crucial element is to transform scientific knowledge into impact outside of science (Douthwaite et al. 2007; Sarewitz et al. 2004). The process of creating impact-thus describing the relation between science and societal aspects-can be illuminated through the concept of "innovation".

Until today, innovation is predominantly interpreted as an economy-related concept. For analysing science for sustainable development, more encompassing conceptualisations are more suitable, however. Innovation then refers to any novelty implemented in a specific context or to the process of its implementation. In this definition, innovation is not necessarily aimed at economic benefits (Röling 2009). Objects of innovation can be material phenomena, such as a technology, or non-material innovations, such as a new technique, organisational or process-related changes, or social processes (Ul Hassan et al. 2011). Potentially, science-based innovations thus may have various entry points to "the real world". Scientific results may be adopted in the form of an innovative technology, product, or process that leads, for example, to better medical treatments, enhanced food security, or improved adaptation to climate change (Arocena and Sutz 2012; Conway et al. 2010; Douthwaite 2002; Hornidge 2013; Röling 2009; Smith 2009; STEPS Centre 2010). Or they may inspire social innovation, for example, changing public perceptions and individual behaviour, or influencing social or economic policies and governance structures (Sumner et al. 2009).

Transdisciplinary knowledge creation is widely believed to be a mode of research that corresponds well to the objective of applied science for sustainable development. It has been put into practice in transnational research cooperation and, subsequently, the concept has been taken up in policy 
advice and by policy-makers as an adequate form of effective, science-based problem-solving (Jahn et al. 2012). As a mode of science, transdisciplinarity is recommended to-and applied within - the development research community as well as in sustainability research to create impact beyond publications or patents (KFPE 1998; Stöckli et al. 2012). Transdisciplinary approaches are characterised by problem-orientation, policy-orientation, and/or impactorientation. In all stages of the research process, partners from academia, civil society, and policy are involved; this is perceived to ensure relevant and suitable results and solutions (Lang et al. 2012; Lyall 2008; Mollinga 2008; Pohl and Hirsch Hadorn 2008). The concept of transdisciplinarity entails the idea of respecting and appreciating diverse knowledge on equal footing. In view of North-South cooperation, symmetric partnerships between researchers from developed countries and developing countries that are based on mutual interest and ownership-including joint agenda-setting, decisionmaking, implementation, and management-are strived for, but also critically reflected on (see, among others, Bradley 2007; KFPE 1998; Stöckli et al. 2012; Wiesmann et al. 2011; Zingerli 2010). Transnational transdisciplinary cooperation may face difficulties in practice, for example, when certain partners lack adequate funding, or when different partners have different problem definitions. In addition to different socio-economic, institutional, and epistemic backgrounds, diverging research interests and a lack of methodologies on international cooperation can lead to reproducing (neo)colonial patterns or patronage relationships as well as enhancing power imbalances (Bradley 2007; Fuest 2005, 2007; Grosfoguel 2013; Maselli et al. 2006; Zingerli 2010). It is therefore necessary to align practices on the ground with the normative discourse on transdisciplinary partnerships. Although practice and theory thus may deviate, as in other types of cooperation, transnational transdisciplinary cooperation is still believed to be a valuable principle for coming up with implementable solutions as well as an even distribution of benefits stemming from the research process, thereby providing a fruitful mutual experience for all parties involved in the partnership (STEPS Centre 2010; Stöckli et al. 2012).

Next to the potential benefits, more reflexive accounts of the impacts of applied science on society also acknowledge the potential of negative or unintended consequences or trade-offs. ${ }^{6}$ For example, science-based innovations leading to economic growth might aggravate inequality at the same time; medical research might not produce the expected impacts on reducing infection rates among certain social groups; or the introduction of a new drought-resistant crop variety might lead to abandoning a more nutritious one (Douthwaite et al. 2001; Sarewitz et al. 2004; Smith 2009).

The scope and the scale addressed through both the science on and for sustainable development may differ. In view of scope, research may focus on isolated dimensions of sustainable development, such as ecological problems, or it may investigate phenomena from a more encompassing perspective and consider social and economic aspects alongside ecological ones, thus displaying 
a larger conceptual scope. It may also focus on interconnections or tradeoffs between dimensions of sustainable development. In view of scale, research perspectives may address an overarching systemic level, such as a country's innovation system, or it may address the transformation of society as a whole towards sustainability (Geels 2004; Geels and Schot 2007; WBGU 2011). On a smaller scale, research may also target problem analysis and find solutions to concrete sustainability issues at a context-dependent, problem-specific level (Rhodes and Sulston 2009; Sumner et al. 2009). The proposed categories, as often is the case, are not clear-cut but may overlap and blur. Nevertheless, they serve to distinguish between some characteristic features of research on and for sustainable development.

\subsection{Governing Science In the ConteXt of the 2030 Agenda}

The role of science for and on sustainable development and research cooperation between partners of the Global North and the Global South in global governance as well as national German science policy are the subjects of this section. As shown in Sect. 4.3, science as a specific type of knowledge can be an important cornerstone of sustainable development. Inter- and transnational cooperation play an essential role in interlinking partners and bodies of knowledge globally.

National policies as well as internationally and globally agreed norms are necessary to guide its shape, however. Scholars point to the essential role that policies play in setting a future course for framing societal problems, solutions, and standpoints (Clay and Schaffer 1984). Due to the internationalisation of research and worldwide spread of the technologies produced, national science policies oriented towards international cooperation influence scientific networks and cooperation and become important next to policies focussed on the local or national level (European Commission 2009; Smith 2009; The Royal Society 2011).

At the same time, global norms and agreements in other fields of international cooperation, such as development cooperation, also potentially influence inter- and transnational research cooperation. Hence, norms, agreements, and policies themselves turn into topics of interest, as they set the conditions for cooperation in research to have positive impacts on society, such as sustainable development (Bucar 2010; STEPS Centre 2010).

\subsubsection{German Policies for Science Cooperation Versus Policies for Development Cooperation}

Transnational research cooperation between partners in the Global North and the Global South touches the political fields of both development policy and science policy. The German case provides an empirical illustration of the importance of the specific political framework of research cooperation between 
the Global North and South, which determines its potential effects. Although countries differ in view of their political institutions-and the findings therefore cannot be generalised - the separation of policy fields into science policy, on the one hand, and development policy, on the other, can be commonly observed. Along the German example, I argue that the coherence of science policy and development policy objectives on the country level might benefit from a closer focus of global governance mechanisms on the role of research cooperation between the Global South and North-and that it is therefore a worthwhile scientific endeavour to analyse the political context in different national political set-ups.

In the German context, the Federal Ministry of Education and Research $(\mathrm{BMBF})$ is the largest provider of public funds for research cooperation between German researchers and partners in the Global South. Decisively setting the course of cooperation, the policies for research cooperation with developing countries or emerging economies are a field of science policy and not the policies of the Federal Ministry for Economic Cooperation and Development (BMZ). The same division of responsibilities holds true in the European Union (EU), which funds research cooperation between EU member states and developing countries and emerging economies within its Framework Programme for Research and Innovation, which is currently Horizon 2020 (BMBF 2008; European Commission 2015). In other European countries, such as Switzerland and France, the policies and funding for research cooperation are the shared responsibilities of both the ministries of science as well as the ministries of development cooperation (Institut de recherche pour le développement 2012; KFPE 2013).

In view of funding research cooperation with the Global South, the BMBF provides the largest amount of public funding in Germany. BMBF expenditures for cooperation with BRICS countries alone amounted to approximately $€ 47$ million in 2012 (BMBF 2014b). In view of BMBF funding for cooperation with other countries of the Global South, the only numbers available were those reported as official development assistance (ODA) expenditures, which increased from $€ 112.7$ million in 2012 (BMZ 2013) to $€ 149.9$ million in 2015 (Bohnet et al. 2018). Quite likely, these figures include activities of cooperation in education as well as research. Other official sources state that between 2011 and 2015 , the BMBF allocated $€ 206$ million to cooperation with African partner countries (18. German Federal Parliament 2017). The BMBF's Subdepartment for Sustainability, Climate, Energy has the longest tradition of cooperating with countries of the Global South-both on a political level as well as in funding cooperative research. As with other BMBF research programmes, its framework programme Research for Sustainability Development (FONA) is primarily dedicated to supporting German researchers. Nevertheless, in the scope of the programme, many initiatives for cooperation between Germany and the Global South have been funded. The importance given to the international dimension of sustainability and environmental issues is shown in the high amount of expenditures for inter- and 
transnational cooperation, which amounted to 20 per cent of the total funds of FONA, $€ 100$ million per year, from 2010 to 2014 (Fischer and Mennicken 2013). Larger funding initiatives for research cooperation with partners in the Global South include funding initiatives on Integrated Water Resources Management (IWRM) (BMBF 2004a) and sustainable Megacities (BMBF 2004b), as well as the establishment of two Regional Climate Science Service Centres in Western and Southern Africa in 2010, now in their second funding phases (BMBF 2019).

The BMZ funds activities within higher education and research, including individual scholarships and university partnerships for science management, with approximately $€ 50$ million per year (18. German Federal Parliament 2017). The BMZ's policies for research cooperation, as part of the development policy portfolio, are often coupled with (higher) education (BMZ 2015). BMZ programmes instead target infrastructural measures and capacity development in the higher education sector. For example, the BMZ supports cooperation with higher education institutions in developing countries, aligning curricula to job market demands, sharpening research profiles, and fostering internationalisation. In addition, the BMZ funds some research through intermediary organisations, such as the German Academic Exchange Service (DAAD), the Alexander von Humboldt Foundation, and the Deutsche Gesellschaft für Internationale Zusammenarbeit (GIZ). For example, funded through the BMZ, the DAAD and GIZ cooperated with the Commission of the African Union to set up the Pan African University's Institute of Water and Energy Sciences. Aiming at fostering higher education, science, and technological development across Africa, the Pan African University established new institutes at existing research centres in addition to educating postgraduates as well as $\mathrm{PhD}$ candidates and conducting applied research (German Academic Exchange Service 2016; Gesellschaft für Internationale Zusammenarbeit 2016). Distinguishing more specifically between funding for higher education and funding for research, as such, shows that although higher education is funded comprehensively within the BMZ's portfolio, compared to other sources of research cooperation funding - and also compared to the BMZ's overall expenditures - its funds for research-related activities are small (BMBF 2014b).

\subsubsection{Coherence of German Science Policy and Development Policy}

Next to the source of funding for research cooperation between partners of the Global North and the Global South, the policy objectives of different ministries also vary. In view of the policies for research cooperation, the different institutional and discursive frameworks of the BMBF and the BMZ influence the objectives, mode, and target groups of cooperation. This is essential, also in view of policy coherence for development. 
The BMBF, as such, is not primarily aimed at international policy-making, but rather focusses on the German national context in its policies and funding measures. Nevertheless, international cooperation is part of its policy spectrum. Across its departments, the BMBF funds international research cooperation within the scope of different strategies, within different funding initiatives, with different partner countries, on different topics, and with different objectives (BMBF 2014c). The motivation for funding research cooperation with developing and emerging countries is not predominantly a concern for global sustainable development. It is of equal importance to foster German interests, such as positioning Germany as a player on future markets or contributing to technology exports (Schwachula 2019). ${ }^{7}$

To ensure policy coherence, ministries are legally obliged to cooperate with the Joint Rules of Procedure of the Federal Ministries (Cabinet of Germany 2011). At the same time, the German constitution grants a high degree of autonomy to each ministry, which counteracts coherence. In this sense, the fate of the Internationalisation Strategy (BMBF 2008, 2016), which was issued by the $\mathrm{BMBF}$ but is inter-ministerial in scope, and the International Cooperation Action Plan (BMBF 2014a) is illustrative. Although on paper the documents set an overarching framework for funding international cooperation in education and research across the entire German government, the documents are not binding.

In addition, policy coherence is endangered by rivalries between ministries. Instead of viewing ministries as non-political entities of administration, the relations between the BMBF and the BMZ illustrate that policy-makers also defend their political turf, especially when policy fields overlap. Policies, programmes, and funding measures are the outcomes of previous processes of policy-making, and therefore they are the products of knowledge politics, of strategic or coincidental integration, or the inclusion of different actors in the policy process. They are subject to bureaucratic rules and regulations and coined by pre-existing norms, values, and beliefs, which finally crystallise in policies.

I argue that the causes of incoherent policies lie within the different logics and perspectives on cooperation with the Global South. Neither the processes of policy-making nor policy outcomes are reconciled, as the BMBF aims to maintain its own political autonomy, whereas the BMZ is not in a position to prescribe policy coherence for development (Schwachula 2019). Despite distancing itself from the policy rationales of the BMZ, however, the BMBF is able to report some of its activities as ODA, contributing 0.9 per cent of the German ODA quota, which ranked it fourth among the German federal ministries in 2015 (Bohnet et al. 2018). 


\subsubsection{Global Governance of Science for Sustainable Development}

More traditional types of development cooperation are defined, negotiated, and aligned on the global level in view of their modes of cooperation, thematic responsibilities, and development targets, such as the SDGs. Hence, global governance structures are in place for development cooperation. In contrast to other types of cooperation, however, science cooperation between the Global North and South has received little attention in global governance and is barely regulated. Thus, research cooperation is nationally and internationally mostly "ungoverned", which is surprising in view of its high potential as a type of cooperation conducive to sustainable development and the SDGs, in particular. The existing institutions and norms of (sustainable) development on the global scale curiously still have not put North-South research cooperation into the spotlight.

International development agreements such as the Paris Declaration on Aid Effectiveness, its follow-up Accra Agenda for Action (Organisation for Economic Co-operation and Development [OECD] 2008), the Busan Partnership for Effective Development Co-operation (OECD 2011), and the following GPEDC set an overarching framework for national policies, such as the development policy of the BMZ, as well as for non-state action.

In contrast to development policy, the BMBF's science policy, which is directed at transnational cooperation, is not bound to fulfilling international agreements relating to sustainable development, such as the 2030 Agenda and its SDGs. Thus, international development targets and agreements are of subordinate importance for the political framing of science cooperation between the Global North and the Global South. BMBF funding for research on sustainable development, in cooperation with partners from the Global South, may be reported as part of German ODA-but it does not have to be. The BMBF could use at least part of its resources to fund entirely different research activities. International political agreements in the context of the G20 rarely address the role of science cooperation for sustainable development (Cabinet of Germany 2018).

Separate international and global policies or governance mechanisms for transnational research partnerships between the Global North and the Global South, as an equivalent to development cooperation, do not exist. In view of principles of cooperation and their conduciveness to sustainable development, transnational research cooperation in practice often takes place outside of global agreements. The 2030 Agenda, as such, does not specifically conceptualise knowledge or science cooperation as a contribution to development cooperation. In its portrayal of knowledge for development, the document remains ambiguous and vague. Although it portrays the SDGs as global, encompassing concerns, science is mainly portrayed in view of its economic viability, for example through technology development. Although SDG target 17.6 specifically calls for science cooperation-including North-South, SouthSouth, and triangular cooperation-it only relates to technology development. 
Next to technology development, the 2030 Agenda specifically refers to the accompanying task of research, such as developing indicators and monitoring implementation. In the agenda, the institutionalisation of an online platform for information on existing science and technology initiatives is called for (however, such a platform was only available in a test version at the time of research) (UN 2018a). Institutions surrounding the 2030 Agenda, such as the High-level Political Forum on Sustainable Development (HLPF), and the voluntary national reviews rely on scientific data collection for the SDGs. Results of a yearly UN-convened Multi-stakeholder Forum on Science, Technology and Innovation for the Sustainable Development Goals are fed into the HLPF (UN 2018b). The UN additionally mandates an international group of scientists with elaborating a science-based Global Sustainable Development Report for strengthening science-policy interfaces (UN 2018c).

Beyond technology development and accompanying research on sustainable development, however, the 2030 Agenda, as such, does not refer to transnational research cooperation as a beneficial type of partnership for encompassing sustainable development. Target 17.16, on multi-stakeholder partnerships, makes no reference to science, or to different types of knowledge at all (UN 2015). Cummings et al. therefore conclude "that there is a mismatch between the transformative vision and strategy within the SDGs and the nontransformative nature of the means of implementation and the goals and targets" and call for a more inclusive, pluralist perspective on knowledge for development (Cummings et al. 2018, p. 738).

The development-related agreements, institutions, and norms established by the members of the Organisation for Economic Co-operation and Development (OECD) do not cover the role of science, as such-more specifically, they also do not adequately cover the role of research cooperation between partners of the Global North and South. The Paris Declaration (2005) does not allude to science or research at all. The Accra Agenda for Action mentions research institutes only in the context of taking "an active role in dialogue on development policy and on the role of aid in contributing to countries' development objectives" (OECD 2008, p. 16). The Busan Partnership Agreement, while highlighting the role of new actors in cooperation and alluding to the importance of knowledge, does not consider the role of science beyond its role of monitoring and assessing the performance of development institutions (OECD 2011). Following up on the Busan Partnership Agreement, the GPEDC, as a shared initiative between the UN and the OECD, aims at effective partnerships for reaching the 2030 Agenda. It is based on four principles: joint ownership, focus on results, inclusive development partnerships, transparency and accountability (OECD and UNDP 2019). Although it promotes a "whole of society approach to development", the role of cooperation with research is neglected, whereas multi-stakeholder partnerships with civil society organisations and the private sector are specifically encouraged. 
The GPEDC attributes a substantial role to monitoring, data, and evidence, and thus to research accompanying the implementation of the GPEDC's objectives (OECD and UNDP 2019). The GPEDC also acknowledges the important role of knowledge for development. As an objective, the work programme of 2017/2018 stated that knowledge sharing should be enabled by "[b]ringing together the learning, knowledge and technology available across constituencies to help scale development solutions at a faster pace" (GPEDC 2017, p. 5). Aiming at developing into a knowledge-sharing hub for development actors on different levels, the GPEDC also established an online knowledge platform as a "one-stop shop to evidence-based solutions, peer learning and networking to advance the effectiveness of all development efforts, for achievement of national priorities and the SDGs" (GPEDC 2019). However, researchers are not among the listed social actors for cooperating in development, nor is science included as a topic of discussion in view of its potential benefits.

The neglect of research cooperation in development norms and partnerships is mirrored in the low levels of research funding officially reported as ODA, although the OECD Development Assistance Committee's (DAC) reporting directives for ODA actually would allow research activities to be reported as ODA:

Research includes financing by the official sector, whether in the donor country or elsewhere, of research into the problems of developing countries. This may be either (i) undertaken by an agency or institution whose main purpose is to promote the economic growth or welfare of developing countries, or (ii) commissioned or approved, and financed or part-financed, by an official body from a general purpose institution with the specific aim of promoting the economic growth or welfare of developing countries. (OECD-DAC Working Party on Development Finance Statistics 2018, p. 30)

Interestingly, thus, the OECD reporting guidelines deviate from the GPEDC's discourse by specifically mentioning research as a means of ODA. For both GPEDC documents as well as 2030 Agenda documents, it holds true thatbeyond a very general reference to research for development, that is, research on the problems of the Global South, or technology-oriented research and innovation ${ }^{8}$-none of the documents or knowledge platforms suggest any rules or guidelines on the role of research, as such, or on principles of cooperation in transnational research. Accordingly, neither topics, nor principles, nor modes, nor partner regions of cooperation are regulated-none are incentivised, none are forbidden. Potentially, any researchers from the Global North may decide to cooperate with partners in the Global South on almost any given topic, in any given mode- and potentially also report it as ODA.

I argue that it is worthwhile to scrutinise the gaps in global governance for research cooperation between partners in the Global South and North, as they may aggravate policy incoherence on the national level. The example of 
Germany illustrates that, without informal agreements or formal rules on the international or global level, science policy for international cooperation may pursue objectives that are detached from-and potentially even run contrary to-those of development policy. In addition, the lack of detailed criteria for reporting science cooperation may have detrimental effects: In practice, this leads to research partnerships that are reported as ODA while not meeting the partnership principles agreed upon, as I elaborate below.

In appraising the absence of regulations and norms-both formal and informal-for transnational research cooperation, the concept of freedom of research has to be taken into account, a freedom that is granted to research in most democratic national constitutions in the Global North as well as the Global South. Some philosophers of science even perceive the autonomy of science as being the crucial element of ensuring its creativity and productivity (Polanyi 2000). In the science systems of most countries, science policy enables curiosity-driven, autonomous research, while also guiding research towards specific societal aims.

Science is thus promoted as a means of reaching an objective beyond science, within other parts of society (Sarewitz et al. 2004; Sarewitz and Pielke 2007). In consequence, research cooperation is never entirely free of being governed. Research on some topics or locations is restricted or enabled by certain rules: For example, ethical principles for medical research, aimed at protecting the rights and lives of research participants, are internationally agreed upon (World Health Organization 2019). On topics such as nuclear research, transnational research cooperation is restricted due to security issues, for example, between EU countries and Iran (DLR Project Management Agency 2019).

However, governing science does not always imply that it is restricted. Conventions, rules, and norms may also enable or incentivise certain types of science or research cooperation. For example, in an attempt to enable scientific cooperation, the Arctic Council issued an agreement on research cooperation in and on the Arctic (Arctic Council 2017). In this light, global agreements may help guide transnational research cooperation between the Global South and the Global North towards becoming more conducive to sustainable development.

An explicit normative framework for research cooperation on the global level entailing principles of fair and successful cooperation, such as partnership, ownership, and benefit-sharing, might enhance policy coherence in, for example, the German case, where national science policies for transnational cooperation with the Global South are not aligned with policies for sustainable development. The field of science policy, even if it is oriented towards transnational cooperation with the Global South, is untouched by any global norms or regulations, thus it is open to deviations from globally agreed targets. In the German context, the bargaining power of actors within the BMBF, who pursue development-oriented targets of research policy, may be strengthened by integrating science cooperation among Northern and Southern partners 
more explicitly into the global development agenda. It would provide additional global legitimation for research policies targeting global development, which often compete against nationally oriented policy rationales. A focus on research partnerships on the global agenda might also strengthen the position of the $\mathrm{BMZ}$ or comparable development ministries where it concerns the enforcement of policy coherence of other political fields with developmental objectives.

The process of the policy design of older German funding initiatives for international cooperation, such as the IWRM initiative (BMBF 2004a) and the Megacities initiative (BMBF 2004b), illustrates why gaps in global governance mechanisms, in view of transnational research, may have detrimental effects. Both funding measures were aimed at cooperation with different partner countries in the Global South, ranging from Namibia, Uzbekistan, Mongolia, Brazil, Iran, and Peru to South Africa, among others. Despite their international focus, the funding programmes were unilaterally designed by the BMBF according to German research interests, and in the case of the IWRM initiative, also according to German business interests. ${ }^{9}$ They were not co-designed or co-financed by partner countries. Hence, this exclusion of Southern partners in setting agendas and designing cooperation policies ran contrary to any principles of ownership and partnership, as specified in the GPEDC. Furthermore, the mode of agenda-setting as well as the funding modalities, which only allowed for minimal funds for Southern researchers, had severe consequences for the transnational research projects implemented. Effects ranged from practical problems, such as finding funding for researchers in the Southern partner country, to the ethical problem of repeating old patterns of cooperation between well-paid foreign experts and local researchers as mere recipients of knowledge-and in some cases the effects led to promoting technologies as a solution at the expense of social or other types of innovation (Schwachula 2019). Despite this mismatch with norms for development cooperation, research cooperation projects such as those in the IWRM and Megacities funding initiatives were reported as ODA. This phenomenon is not restricted to Germany; similar criticism has been voiced in view of the British Global Challenges Research Fund for not supporting equitable partnerships, despite being reported as ODA (Fransman and Newman 2019).

More recent science cooperation funding, such as the BMBF's GermanAfrican Regional Science Service Centres, offers examples of more inclusive agenda-setting and policy design. During the creation of these centres, the BMBF and the governments of Southern and West African countries negotiated on topics and funding before the large-scale projects were initiated in 2010. These projects were reported as ODA and also complied with internationally agreed partnership principles of development cooperation. This, however, was a lucky coincidence of voluntary alignment and cannot be attributed to a steering effect of the global governance framework, as such. 


\subsection{CONCLUSIONS}

As argued throughout this contribution, research cooperation between the Global North and the Global South may be a complementary means of reaching the SDGs. It should therefore be raised onto the global development agenda. Providing a conducive normative framework for transnational research cooperation between partners of the Global South and North could also contribute to setting the conditions right for fair, fruitful, and thereby "successful" cooperation. Although the inclusion of different stakeholdersalong with their perspectives and types of knowledge-is often portrayed as the most effective way of solution-oriented research, the appreciation of diverse bodies of knowledge is also a matter of mutual respect as an intrinsic value. In this sense, principles for transnational cooperation in research should extend beyond principles of effectiveness, as in the GPEDC's definition: Next to the effective production of relevant new knowledge, principles of research cooperation should also include the ideas of fairness and equity within the partnership (Fransman and Newman 2019). Beyond the impacts of creating new knowledge, adding fairness and equity as partnership principles can contribute to structural changes, such as more equity in the global system of knowledge production and representation, thereby also counteracting global inequalities, as such.

As shown in Sect. 4.3, in the context of sustainable development, science cooperation potentially is a form of knowledge cooperation among equal partners who jointly produce relevant new insights and generate innovations for sustainable development. It is important to point out that equity in this sense does not refer to the level of integration into the global system of science. This would require all partners to start from a level playing field, which at present is not given, due to the existing inequalities in the global system of science production and representation and different levels of access to funding. Fairness and equity as key elements of cooperation are rather an approach towards appreciating diverse stances, perspectives, and knowledge in research cooperation. Filling these principles with life means enabling all partners to partake in agenda-setting, decision-taking, and the process of research on equal footing, thereby fostering all partners to become independent players within the global system of science production and representation in the long run.

In contrast to knowledge transfer from Northern partners to Southern partners, cooperation in research offers the potential for cooperation on equal terms. It is therefore highly suitable to put the new global development paradigm into cooperation practice. However, although science cooperation between partners in the Global South and the Global North has a high potential for contributing to sustainable development, its potential is currently not being fully tapped. Without regulating modes of agenda-setting for research cooperation, and without incentivising cooperation on certain topics, national policy-makers for science cooperation may frame science and development issues and direct the flows of research funds according to political priorities-possibly negatively affecting the SDGs. 
Despite a shifting paradigm towards "global development", entailing the idea that all types of knowledge and experiences count (Horner and Hulme 2017), technology transfer and capacity development continue to be the most common knowledge-related modes of cooperation, firmly grounded in the ongoing development norms, including the 2030 Agenda as well as the GPEDC. However, these activities essentially aim at knowledge flows from knowledgeable, that is, Northern partners, to those partners in the South who need to "catch up" knowledge-wise, thus following a Western or Northern model of development and modernity (Shamsavari 2007; Smith 2009). Hence, despite contrary global rhetoric, the idea of one-way knowledge transfer or capacity development, which is inherently based on the assumption of a superiority of Western or Northern knowledge, persists in development policy and practices.

However, we face times of shifting global power constellations, combined with an urgency of combating climate change and the necessity of turning towards more sustainable development pathways worldwide. In this regard, science cooperation seems to be an adequate cooperation pattern. Research cooperation may inspire leapfrogging developments in the Global South and lead to the development of alternative solutions for the Global North. In consequence, jointly producing new knowledge through research, as well as exchanging knowledge on equal terms, should receive much more attention as adequate types of knowledge cooperation for achieving sustainable development. If sustainable development is taken seriously as a global agenda, the mode of cooperation should mirror the fact that partners from all countriesas developing countries in certain aspects of social, economic, or ecological development-need access to new knowledge, and thus a one-way transfer of knowledge will not suffice. Instead, partners need to jointly create novel insights.

Specific topics of sustainable development that affect partners on both sides could present starting points for comparative research in international teams. Issues such as social inequality on different scales, carbon-neutral development, sustainable urban development, and sustainable production and consumption present challenges in most countries (WBGU 2011, 2016). Research cooperation on these topics might enhance mutual learning instead of repeating traditional patterns of cooperation; jointly developing pathways might enable sustainable development in all partner countries.

At the moment, the gaps in global governance in view of sustainabilityoriented transnational research cooperation pose a risk rather than an opportunity: First, the gap negatively affects the coherence of development policy and research policy at the national level. Second, the gap enhances the risk of research cooperation reproducing antiquated patterns of North-South cooperation, thereby reifying global inequalities; third, the gap in global governance bears the risk of turning certain sustainability-related problems into global "orphan issues" that lack funding structures as well as powerful speakers raising 
these topics on the national science policy agenda; and fourth, the potential of research cooperation to develop innovative solutions for sustainable development is not being adequately tapped.

An agreement on transnational research cooperation between partners in the Global North and the Global South would therefore be beneficial. Such an agreement should first, enhance an equitable mode of cooperation among different stakeholders (inter- and transdisciplinary); second, enable science cooperation in view of sustainability topics on various scales (local and global; problem-specific or systemic entry points), and it should third, support openended, reflexive research for all kinds of solutions, ranging from social to technological innovations.

\section{Notes}

1. In this paper, the terms "research cooperation" and "science cooperation" are used interchangeably.

2. The term "Global South" is used here to depict the countries located mainly in the Global South that are enlisted as recipients of official development assistance (ODA) by the Organisation for Economic Co-operation and Development (OECD), which in turn draws on the World Bank's numbers on gross national income (OECD 2018).

3. Successful examples include different types of innovations stemming from transdisciplinary, transnational research cooperation projects focussed on sustainable urbanisation and sustainable water management between partners from Germany and the Global South. Solutions ranged from city development plans to decision support systems, governance schemes, eco-parks, water treatment facilities, and awareness-raising activities, among others (Schwachula 2019).

4. In this sense, Kuhn's seminal work on scientific "paradigms" (1962) as well as Foucault's work on "epistemes" (Foucault 2005 [1966]; 1972) show how scientific knowledge is enabled, limited, directed, interrupted, and re-interpreted through specific underlying meaning schemes; Knorr-Cetina (1999) demonstrates that different types and institutions of knowledge production disintegrate science into scattered disciplines with their own standards, definitions, modes, and world views.

5. It remains to be investigated if the rise of Southern scientific powers leads to changes within the global system of knowledge production in the long run, comparable to the changes occurring with the rise of Southern donors and South-South cooperation in technical development cooperation.

6. In the light of the potential positive or negative impacts of solution-oriented research, traditional indicators of research success, such as bibliometric data, are not adequate, as they do not measure any effects outside of the science system. Impact measurement of science, however, is difficult and still in an early stage (Douthwaite 2002; Douthwaite et al. 2007; Ely and Oxley 2014; Martin 2011; Maselli et al. 2006; STEPS Centre 2010; Sumner et al. 2009).

7. Based on a constructivist understanding, I consider policy and funding initiatives as concrete outcomes of knowledge exchange and negotiations among different actors, with different levels of power, pursuing different objectives in view of global, inter- and transnational cooperation in research. 
8. As previously analysed, the OECD and the UN have a history of conceptualising science, technology, and innovation, mainly with regard to their economic viability (Schwachula et al. 2014).

9. Viewed from a development perspective, the practice of technology-export to the Global South through research cooperation (ODA-classified) might be categorised as "informal tied aid", which scholars perceive as being potentially harmful and a hindrance to sustainable development in developing countries (Carbone 2014).

\section{REFERENCES}

18. German Federal Parliament. (2017). Unterrichtung durch die Bundesregierung: Strategie der Bundesregierung zur Internationalisierung von Bildung, Wissenschaft und Forschung (Drucksache 18/ 11100). Berlin: Cabinet of Germany.

Acosta Espinosa, A. (2008). El buen vivir, una oportunidad por construir. Ecuador Debate, $75,33-48$.

Agrawal, A. (1995). Dismantling the divide between indigenous and scientific knowledge. Development and Change, 26(3), 413-439.

Arctic Council. (2017). Agreement on enhancing international Arctic scientific cooperation. https://oaarchive.arctic-council.org/handle/11374/1916.

Arocena, R., \& Sutz, J. (2010). Weak knowledge demand in the South: Learning divides and innovation policies. Science and Public Policy, 37(8), 571-582.

Arocena, R., \& Sutz, J. (2012). Research and innovation policies for social inclusion: An opportunity for developing countries. Innovation and Development, 2(1), 147158.

BMBF (German Federal Ministry of Education and Research). (2004a). Bekanntmachung von Richtlinien zur Förderung eines Ideenwettbewerbs zur Vorbereitung von Projekten im Rahmen des Förderschwerpunktes "Integriertes WasserressourcenManagement (IWRM) einschließlich des notwendigen Technologie-und Know howTransfers". http://www.bmbf.de/foerderungen/2434.php.

BMBF. (2004b). Bekanntmachung "Forschung für die nachbaltige Entwicklung der Megastädte von morgen”. https://www.bmbf.de/foerderungen/bekanntmachung62.html.

BMBF. (2008). Strengthening Germany's role in the global knowledge society. Strategy of the Federal Government for the internationalization of science and research. Bonn and Berlin: Author.

BMBF. (2014a). The BMBF's international cooperation action plan: Summary of the central points. Berlin: Author.

BMBF (2014b). Bundesbericht Forschung und Innovation 2014. Bonn and Berlin: Author.

BMBF. (2014c). Political staff and organization. http://www.bmbf.de/en/562 5.php.

BMBF. (2016). Internationalisation of education, science and research. Strategy of the Federal Government. Bonn and Berlin: Author.

BMBF. (2019). Afrika: Partner im Kampf gegen den Klimawandel. https://www. bmbf.de/de/afrika-partner-im-kampf-gegen-den-klimawandel-9250.html. 
BMZ (German Federal Ministry for Economic Cooperation and Development). (2013). Mittelherkunft der bi- und multilateralen ODA 2011-2012. Bonn and Berlin: Author.

BMZ. (2015). BMZ education strategy: Creating equitable opportunities for quality education. Bonn and Berlin: Author.

Bohnet, M., Klingebiel, S., \& Marschall, P. (2018). Die Struktur der deutschen öffentlichen Entwicklungszusammenarbeit: Hintergründe, Trends und Implikationen für das BMZ und andere Bundesressorts (Discussion Paper 15/2018). Bonn: Deutsches Institut für Entwicklungspolitik / German Development Institute (DIE).

Bradley, M. (2007). North-South research partnerships: Challenges, responses and trends (IDRC, Canadian Partnerships Working Paper 1). Ottawa, ON: International Development Research Centre.

Bucar, M. (2010). Science and technology for development: Coherence of the common EU ReD policy with development policy objectives (Discussion Paper 19/2010). Bonn: Deutsches Institut für Entwicklungspolitik / German Development Institute (DIE).

Cabinet of Germany. (2011). Joint rules of procedure of the Federal MinistriesGemeinsame Geschäftsordnung der Bundesministerien (GGO). Berlin: Federal Ministry of the Interior, Building and Community.

Cabinet of Germany. (2018). Gruppe der Zwanzig: Wissenswertes rund um die G20. Berlin: Federal Ministry of the Interior, Building and Community.

Carbone, M. (2014). Much ado about nothing? The European Union and the global politics of untying aid. Contemporary Politics, 20(1), 103-117.

Chataway, J., Smith, J., \& Wield, D. (2006). Science and technology partnerships for poverty alleviation in Africa (ESRC Innogen Centre Working Paper 45). Edinburgh and Milton Keynes: ESRC Innogen Centre.

Clay, E. J., \& Schaffer, B. (1984). Room for manoeuvre: An exploration of public policy planning in agricultural and rural development. Cranbury, NJ: Associated University Press.

Conway, G., Waage, J., \& Delaney, S. (2010). Science and innovation for development. London: UK Collaborative on Development Sciences.

Cowen, M. P., \& Shenton, R. R. (2003). Doctrines of development. New York, NY: Routledge.

Crewe, E., \& Harrison, E. (1998). Whose development? An ethnography of aid. London and New York, NY: Zed Books.

Cummings, S., \& Hoebink, P. (2017). Representation of academics from developing countries as authors and editorial board members in scientific journals: Does this matter to the field of development studies? The European Journal of Development Research, 29(2), 369-383.

Cummings, S., Regeer, B., de Haan, L., Zweekhorst, M., \& Bunders, J. (2018). Critical discourse analysis of perspectives on knowledge and the knowledge society within the sustainable development goals. Development Policy Review, 36(6), 727742 .

Della Faille, D. (2011). Discourse analysis in international development studies: Mapping some contemporary contributions. Journal of Multicultural Discourses, $6(3), 215-235$.

DLR Project Management Agency. (2019). Iran: Überblick zur internationalen Kooperation. https://www.kooperation-international.de/laender/asien/iran/zusammenf assung/ueberblick-zur-internationalen-kooperation/. 
Douthwaite, B. (2002). Enabling innovation: A practical guide to understanding and fostering technological change. London and New York, NY: Zed Books.

Douthwaite, B., Alvarez, S., Cook, S., George, P., Howell, J., Mackay, R., et al. (2007). Participatory impact pathways analysis: A practical application of program theory in research-for-development. The Canadian Journal of Program Evaluation, $22(2), 127-159$.

Douthwaite, B., deHaan, N., Manyong, V., \& Keatinge, J. D. H. (2001). Blending "hard" and "soft" science: The "Follow the Technology" approach to catalyzing and evaluating technology change. Conservation Ecology, 5(2), Art. 13. https:// www.ecologyandsociety.org/vol5/iss2/artl3/manuscript.html.

Ely, A., Leach, M., Scoones, I., \& Stirling, A. (2010). A new manifesto for innovation, sustainability and development-Response to Rhodes and Sulston. European Journal of Development Research, 22(4), 586-588.

Ely, A., \& Oxley, N. (2014). STEPS Centre research: Our approach to impact (STEPS Working Paper 60). Brighton: STEPS Centre.

Escobar, A. (1992). Reflections on "development": Grassroots approaches and alternative politics in the third world. Futures, 24(5), 411-436.

Esteva, G. (2010). Development. In W. Sachs (Ed.), The development dictionary: A guide to knowledge as power (2nd ed., pp. 1-23). London and New York, NY: Zed Books.

European Commission. (2009). Drivers of international collaboration in research. In Technopolis Group and Manchester Institute of Innovation Research (Eds.). Brussels: Author.

European Commission (2015). Horizon 2020. http://ec.europa.eu/programmes/ horizon $2020 /$.

Evers, H.-D. (2000). Epistemic cultures: Towards a new sociology of knowledge (Department of Sociology Working Papers 151). Singapore: National University of Singapore.

Evers, H.-D., Gerke, S., \& Menkhof, T. (2006). Wissen und Entwicklung-Strategien für den Aufbau einer Wissensgesellschaft (ZEF Policy Briefs 6). Bonn: Center for Development Research (ZEF).

Fischer, A., \& Mennicken, L. (2013). FONA international: Innovation und Umsetzung. Presented at the 10. BMBF-Forum für Nachhaltigkeit, Leipzig. Bonn: Federal Ministry of Education and Research.

Foucault, M. (1972). The archaeology of knowledge-l'archéologie du savoir. New York, NY: Pantheon.

Foucault, M. (1980). Power/knowledge: Selected interviews and other writings, 1972 1977. C. Gordon (Ed.). New York, NY: Pantheon Books.

Foucault, M. (2005). The order of things: An archaeology of the human sciences-les mots et les choses. London and New York, NY: Routledge.

Fransman, J., \& Newman, K. (2019). Rethinking research partnerships: Evidence and the politics of participation in research partnerships for international development. Journal of International Development, 31(7), 523-544.

Fuest, V. (2005). Partnerschaft, Patronage oder Paternalismus? Eine empirische Analyse der Praxis universitärer Forschungskooperation mit Entwicklungsländern (ZEF Working Paper Series 9). Bonn: Center for Development Research (ZEF).

Fuest, V. (2007). German-African research co-operation: Practices, problems and policies. Africa Spectrum, 42(3), 483-505. 
Gardner, K., \& Lewis, D. (2000). Dominant paradigms overturned or "business as usual"? Development discourse and the white paper on international development. Critique of Anthropology, 20(1), 15-29.

Geels, F. W. (2004). From sectoral systems of innovation to socio-technical systems: Insights about dynamics and change from sociology and institutional theory. Research Policy, 33(6-7), 897-920.

Geels, F. W., \& Schot, J. (2007). Typology of sociotechnical transition pathways. Research Policy, 36(3), 399-417.

German Academic Exchange Service. (2016). Pan African University (PAU). https://www.daad.de/en/information-services-for-higher-education-institutions/ further-information-on-daad-programmes/pauwes/.

Gesellschaft für Internationale Zusammenarbeit. (2016). Ein Wissenschaftsnetzwerk für Afrikas Entwicklung: Die Panafrikanische Universität. https://www.giz.de/de/wel tweit/26267.html.

Gibbons, M., Limoges, C., Nowotny, H., Schwartzman, S., Scott, P., \& Trow, M. (1994). The new production of knowledge: The dynamics of science and research in contemporary societies. London: Sage.

Glerup, C., \& Horst, M. (2014). Mapping “social responsibility” in science. Journal of Responsible Innovation, 1(1), 31-50.

Gore, C. (2000). The rise and fall of the Washington Consensus as a paradigm for developing countries. World Development, 28(5), 789-804.

GPEDC (Global Partnership for Effective Development Co-operation). (2017). 2017 and 2018 programme of work. http://effectivecooperation.org/wp-content/upl oads/2017/05/2017-18-Global-Partnership-Work-Programme.pdf.

GPEDC (2019). GPEDC knowledge platform. https://knowledge.effectivecooper ation.org/.

Grosfoguel, R. (2013). The structure of knowledge in Westernized universities: Epistemic racism/sexism and the four genocides/epistemicides of the long 16th century. Human Architecture: Journal of the Sociology of Self-Knowledge, 11(1), 73-90.

Hirsch Hadorn, G., Bradley, D., Pohl, C., Rist, S., \& Wiesmann, U. (2006). Implications of transdisciplinarity for sustainability research. Ecological Economics, 60(1), 119-128.

Horner, R., \& Hulme, D. (2017). Converging divergence? Unpacking the new geography of 21st century global development (GDI Working Papers 2017-010). Manchester: University of Manchester.

Hornidge, A.-K. (2012). "Knowledge" in development discourse: A critical review. In A.-K. Hornidge \& C. Antweiler (Eds.), Environmental uncertainty and local knowledge: Southeast Asia as a laboratory of global ecological change (pp. 21-54). Bielefeld: Transcript.

Hornidge, A.-K. (2013). "Knowledge", "knowledge society" \& "knowledge for development": Studying discourses of knowledge in an international context. In R. Keller \& I. Truschkat (Eds.), Methodologie und Praxis der Wissenssoziologischen Diskursanalyse (Vol. 1, pp. 397-424)., Interdisziplinäre Perspektiven Wiesbaden: Springer VS Verlag.

Hornidge, A.-K. (2014a). Wissensdiskurse: Normativ, faktisch, hegemonial. Soziale Welt, 65, 7-24.

Hornidge, A.-K. (2014b). Discourses of knowledge: Normative, factual, hegemonic (Habilitationsschrift). Bonn: Rheinische Friedrich-Wilhelms-Universität Bonn. 
Hulme, D. (2016). Should rich nations help the poor? Cambridge and Malden, MA: Polity Press.

Illi, H. (2001). Development experts at the interface: An inquiry into the knowledge dimension of allocative and strategic action in the arena of a German/Nepalese health development project. Bielefeld: Sociology of Development Research Center, Bielefeld University.

Institut de recherche pour le développement. (2012). IRD annual report. Marseille: Author.

Jahn, T. (2013). Wissenschaft für eine nachhaltige Entwicklung braucht eine kritische Orientierung. GAIA-Ecological Perspectives for Science and Society, 22(1), 29-33.

Jahn, T., Bergmann, M., \& Keil, F. (2012). Transdisciplinarity: Between mainstreaming and marginalization. Ecological Economics, 79, 1-10.

Janus, H., Klingebiel, S., \& Paulo, S. (2015). Beyond aid: A conceptual perspective on the transformation of development cooperation. Journal of International Development, 27(2), 155-169.

Jasanoff, S. (2003). Technologies of humility: Citizen participation in governing science. Minerva, 41(3), 223-244.

Kaldewey, D. (2013). Wabrheit und Nützlichkeit: Selbstbeschreibungen der Wissenschaft zwischen Autonomie und gesellschaftlicher Relevanz. Bielefeld: Transcript.

Keller, R. (2003). Der Müll der Gesellschaft: Eine wissenssoziologische Diskursanalyse. In R. Keller, A. Hirseland, W. Schneider, \& W. Viehöver (Eds.), Handbuch Sozialwissenschaftliche Diskursanalyse (Band 2: Forschungspraxis) (pp. 197-232). Opladen: Leske und Budrich.

Keller, R. (2005). Analysing discourse. An approach from the sociology of knowledge. Forum Qualitative Sozialforschung / Forum: Qualitative Social Research, 6(3), Art. 32.

Keller, R. (2013). Doing discourse research: An introduction for social scientists. Los Angeles, CA: Sage.

KFPE (Commission for Research Partnerships with Developing Countries). (1998). Guidelines for research in partnership with developing countries: 11 principles. Bern: Author.

KFPE. (2010). Weshalb mehr Forschungskooperation mit den Ländern des Südens und Ostens? (Diskussionspapiere der KFPE). Bern: Author.

KFPE. (2013). Jahresbericht 2012 der KFPE. https://naturwissenschaften.ch/organi sations/kfpe/about_kfpe/annual_reports.

Klochikhin, E. A. (2012). Linking development and innovation: What does technological change bring to the society? European Journal of Development Research, 24(1), $41-55$.

Knorr-Cetina, K. (1999). Epistemic cultures: How the sciences make knowledge. Cambridge, MA: Harvard University Press.

Knowledge (2018). In Cambridge Dictionary. https://dictionary.cambridge.org/dic tionary/english/knowledge.

Kuhn, T. S. (1962). The structure of scientific revolutions. Chicago, IL: University of Chicago Press.

Landau, L. B. (2012). Communities of knowledge or tyrannies of partnership: Reflections on North-South research networks and the dual imperative. Journal of Refugee Studies, 25(4), 555-570. 
Lang, D. J., Wiek, A., Bergmann, M., Stauffacher, M., Martens, P., Moll, P., ...Thomas, C. J. (2012). Transdisciplinary research in sustainability science: Practice, principles, and challenges. Sustainability Science, 7(1), 25-43.

Leach, M., Rockström, J., Raskin, P., Scoones, I., Stirling, A., Smith, A., ...Olsson, P. (2012). Transforming innovation for sustainability. Ecology and Society, 17(2), Art. 11.

Lyall, C. (2008). A short guide to designing interdisciplinary research for policy and practice (ISSTI Briefing Notes 6). Edinburgh: Institute for the Study of Science, Technology and Innovation.

Martin, B. R. (2011). The research excellence framework and the "impact agenda": Are we creating a Frankenstein monster? Research Evaluation, 20(3), 247-254.

Maselli, D., Lys, J.-A., \& Schmid, J. (2006). Improving impacts of research partnerships (2nd ed.) (partially revised). Bern: Commission for Research Partnerships with Developing Countries (KFPE).

Mollinga, P. (2008). The rational organisation of dissent: Boundary concepts, boundary objects and boundary settings in the interdisciplinary study of natural resources management (ZEF Working Paper Series 33). Bonn: Center for Development Research (ZEF).

Mosse, D. (2001). "People's knowledge", participation and patronage: Operations and representations in rural development. In B. Cooke \& U. Kothari (Eds.), Participation: The new tyranny? (pp. 16-35). London and New York, NY: Zed Books.

Narayanaswamy, L. (2013). Problematizing "knowledge-for-development". Development and Change, 44(5), 1065-1086.

Nederveen Pieterse, J. (2011). Discourse analysis in international development studies. Journal of Multicultural Discourses, 6(3), 237-240.

Nowotny, H., Scott, P., \& Gibbons, M. (2001). Re-thinking science: Knowledge and the public in an age of uncertainty. Cambridge: Wiley.

OECD (Organisation for Economic Co-operation and Development). (2008). The Paris declaration on aid effectiveness and the Accra Agenda for action. http://www. oecd.org/dac/effectiveness/parisdeclarationandaccraagendaforaction.htm.

OECD. (2011). The Busan partnership for effective development co-operation. https:// www.oecd.org/development/effectiveness/busanpartnership.htm.

OECD. (2018). DAC list of ODA recipients. http://www.oecd.org/dac/financingsustainable-development/development-finance-standards/daclist.htm.

OECD-DAC Working Party on Development Finance Statistics (2018). Converged statistical reporting directives for the creditor reporting system (CRS) and the annual DAC questionnaire. https://one.oecd.org/document/DCD/DAC/STA $\mathrm{T}(2018) 9 /$ FINAL/en/pdf.

OECD \& UNDP. (2019). Making development co-operation more effective: 2019 progress report of the GPEDC (Part I and II). https://www.oecd-ilibrary.org/dev elopment/making-development-co-operation-more-effective_26f2638f-en.

Pohl, C., \& Hirsch Hadorn, G. (2008). Methodological challenges of transdisciplinary research. Natures Sciences Sociétés, 16(2), 111-121.

Polanyi, M. (2000). The republic of science: Its political and economic theory. Minerva, 38, 1-21. 
Rhodes, C., \& Sulston, J. (2009). Scientific responsibility and development. European Journal of Development Research, 22(1), 3-9.

Röling, N. (2009). Conceptual and methodological developments in innovation. In P. C. Sanginha, A. Waters-Bayer, S. Kaaria, J. Njuki, \& C. Wettasinha (Eds.), Innovation Africa: Enriching farmers' livelihoods (pp. 9-34). London: Earthscan.

Sarewitz, D., Foladori, G., Invernizzi, N., \& Garfinkel, M. (2004). Science policy in its social context. Philosophy Today, 48(5), 67-83.

Sarewitz, D., \& Pielke, R. A., Jr. (2007). The neglected heart of science policy: Reconciling supply of and demand for science. Environmental Science \& Policy, 10(1), 5-16.

Schwachula, A. (2019). Sustainable development in science policy-making: The German Federal Ministry of Education and Research's policies for international cooperation in sustainability research. Bielefeld: Transcript.

Schwachula, A., Vila Seoane, M., \& Hornidge, A.-K. (2014). Science, technology and innovation in the context of development: An overview of concepts and corresponding policies recommended by international organisations (ZEF Working Paper Series 132). Bonn: Center for Development Research (ZEF).

Shamsavari, A. (2007). The technology transfer paradigm: A critique (Economics Discussion Paper 4). Kingston upon Thames: Kingston University.

Sillitoe, P. (2000). Let them eat cake: Indigenous knowledge, science and the "poorest of the poor". Anthropology Today, 16(6), 3-7.

Sismondo, S. (2008). Science and technology studies and an engaged program. In E. Hackett, O. Amsterdamska, M. Lynch, \& J. Wajcman (Eds.), The handbook of science and technology studies (pp. 13-31). London and Cambridge, MA: MIT Press.

Smith, J. (2009). Science and technology for development. London: Zed Books.

Smith, A., Fressoli, M., \& Thomas, H. (2014). Grassroots innovation movements: Challenges and contributions. Journal of Cleaner Production, 63, 114-124.

Smith, A., Voß, J.-P., \& Grin, J. (2010). Innovation studies and sustainability transitions: The allure of the multi-level perspective and its challenges. Research Policy, $39(4), 435-448$.

STEPS Centre. (2010). Innovation, sustainability, development: A new manifesto. Brighton: STEPS Centre.

Stock, G., \& Schneidewind, U. (2014, September 18). Streit ums Mitspracherecht. Ein Interview von Christiane Grefe und Andreas Sentker. Die Zeit, p. 41.

Stöckli, B., Wiesmann, U., \& Lys, J.-A. (2012). A guide for trans-boundary research partnerships: 11 Principles / 7 Questions. Bern: Commission for Research Partnerships with Developing Countries (KFPE).

Sumner, A., Perkins, N.I., \& Lindstrom, J. (2009). Making science of influencing: Assessing the impact of development research (IDS Working Papers 335). Brighton: Institute of Development Studies.

The Royal Society. (2011). Knowledge, networks and nations: Global scientific collaboration in the 21st century. London: Author.

Ul Hassan, M., Hornidge, A.-K., van Veldhuizen, L., Akramkhanov, A., Rudenko, I., \& Djanibekov, N. (2011). Follow the innovation-participatory testing and adaptation of agricultural innovations in Uzbekistan: Guidelines for researchers and practitioners. Bonn: Center for Development Research (ZEF). 
United Nations (UN). (2015). Transforming our world: The 2030 Agenda for Sustainable Development. http://www.un.org/sustainabledevelopment/sustainable-develo pment-goals/.

UN. (2018a). Sustainable development goals knowledge platform: technology facilitation mechanism. https://sustainabledevelopment.un.org/tfm.

UN. (2018b). Sustainable development goals knowledge platform: Multi-stakeholder forum on science, technology and innovation for the SDGs (STI Forum). https:// sustainabledevelopment.un.org/TFM/STIForum2019.

UN. (2018c). Sustainable Development Goals Knowledge Platform: Global sustainable development report 2019. https://sustainabledevelopment.un.org/globalsdreport/ 2019.

UN Department of Economic and Social Affairs. (2019). Sustainable Development Goals Knowledge Platform. https://sustainabledevelopment.un.org/.

UN Educational, Scientific and Cultural Organization. (2015). UNESCO science report: Towards 2030 (UNESCO Science Report 2015). Paris: UNESCO Publishing.

UNDP (UN Development Programme). (2013). The Millennium Development Goals: Eight goals for 2015. http://www.undp.org/content/undp/en/home/mdg overview.html.

UNDP. (2018). Human development reports. http://hdr.undp.org/en.

Upreti, B. (2011). Research partnerships and capacity development in the South: A social learning perspective. In U. Wiesmann \& H. Hurni (Eds.), Research for sustainable development: Foundations, experiences, and perspectives (Perspectives of the Swiss National Centre of Competence in Research (NCCR) North-South, University of Bern, Vol. 6.) (pp. 73-90). Bern, Switzerland: Geographica Bernensia.

WBGU (German Advisory Council on Global Change). (2011). World in transitiona social contract for sustainability. Berlin: Author.

WBGU. (2016). Humanity on the move: Unlocking the transformative power of cities. Berlin: Author.

Wiesmann, U., Hurni, H., Ott, C., \& Zingerli, C. (2011). Combining the concepts of transdisciplinarity and partnership in research for sustainable development. In U. Wiesmann \& H. Hurni (Eds.), Research for sustainable development: Foundations, experiences, and perspectives (Perspectives of the Swiss National Centre of Competence in Research (NCCR) North-South, University of Bern) (Vol. 6, pp. 43-70). Bern, Switzerland: Geographica Bernensia.

World Bank. (1999). World development report 1998-1999: Knowledge for development. Washington, DC: Oxford University Press.

World Health Organization. (2019). Ethical standards and procedures for research with buman beings. https://www.who.int/ethics/research/en/.

Ziai, A. (2010). Zur Kritik des Entwicklungsdiskurses. Aus Politik und Zeitgeschichte, 10(Entwicklungspolitik), 23-29.

Ziai, A. (2015). The contribution of discourse analysis to development studies (DPS Working Papers 1). Kassel: Department for Development and Postcolonial Studies.

Ziegler, H. (1998). Brauchen wir eine Wissenschaftspolitik? Eine Polemik. Neue Gesellschaft Frankfurter Hefte, 8, 714-720.

Zingerli, C. (2010). A sociology of international research partnerships for sustainable development. European Journal of Development Research, 22(2), 217-233. 
Open Access This chapter is licensed under the terms of the Creative Commons Attribution 4.0 International License (http://creativecommons.org/licenses/by/4.0/), which permits use, sharing, adaptation, distribution and reproduction in any medium or format, as long as you give appropriate credit to the original author(s) and the source, provide a link to the Creative Commons license and indicate if changes were made.

The images or other third party material in this chapter are included in the chapter's Creative Commons license, unless indicated otherwise in a credit line to the material. If material is not included in the chapter's Creative Commons license and your intended use is not permitted by statutory regulation or exceeds the permitted use, you will need to obtain permission directly from the copyright holder. 